\title{
FUNCTIONAL EVALUATION OF FRACTURE SHAFT OF FEMUR TREATED BY ANTEGRADE CLOSED INTERLOCKING NAIL AT B.P. KOIRALA INSTITUTE OF HEALTH SCIENCES, DHARAN
}

\author{
Gupta $P K^{1}$, Basnet $R^{2}$, Shrestha $N M^{1}$
}

\section{Affiliation}

1. Lecturer, Department of orthopaedic, Birat Medical College and Teaching Hospital

2. Consultant orthopaedic Surgeon, Koshi Zonal Hospital

\section{ARTICLE INFO}

\section{Article History}

Received : 01 August, 2017

Accepted : 22 August, 2017

Published : 31 December, 2017

(c) Authors retain copyright and grant the journal right of first publication with the work simultaneously licensed under Creative Commons Attribution License CC - BY 4.0 that allows others to share the work with an acknowledgment of the work's authorship and initial publication in this journal.

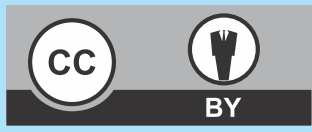

ORA 37

DOI: http://dx.doi.org/10.3126/bjhs.v2i3.18935

* Corresponding Author

Dr. Pradeep Kumar Gupta

Department of Orthopedic

Birat Medical College \&Teaching Hospital, Biratnagar, Nepal Email:pkgupta_22@yahoo.com

\section{Citation}

Gupta PK, Basnet R, Shrestha NM. Functional Evaluation of Fracture Shaft of Femur Treated by Antegrade closed Interlocking Nail B.P. Koirala Institute of Health Sciences, Dharan. BJHS 2017;2(3)4 :244-247

\section{ABSTRACT}

\section{Introduction}

The management of fractures of the femoral diaphysis has changed considerably in the last 30 years. Since the advent and popularization of intramedullary nailing the treatment of fracture shaft of femur has become a good, safe and reproducible procedure for the successful management of fracture shaft of femur.

\section{Objective}

The objective of the study was to assess the various postoperative outcomes of the interlocking nail of fracture shaft of femur.

\section{Methodology}

This study was prospective cohort study conducted at B.P. Koirala Institute of Health Sciences, Dharan from March 2002 to Feb 2004. Seventy five consecutive patients, having fractures shaft of femur were treated by anterograde closed interlocking nail. Data analysis was done by using Epilnfo 2000 software.

\section{Results}

The most common cause of fractures shaft of femur was road traffic accident (69.3\%). The average union time was $14.9 \pm 1.3$ weeks. There was wound infection in four cases superficial infection in open grade II but no deep infection. There was two cases of pudendal nerve pasy which recovered within 4 months. There were 5 cases of broken interlocking distal screw and 4 cases had more than $1.5 \mathrm{~cm}$ shortening of femur

\section{Conclusions}

The antegrade reamed femoral nailing provides excellent results in management of fractures shaft of femur.

\section{KEY WORDS}

Antegrade closed interlocking nail, fractures, shaft of femur 


\section{INTRODUCTION}

The management of fractures of the femoral diaphysis has changed considerably in the last 30 years. Despite the introduction of intramedullary nailing by Hey-Groves ${ }^{1}$ and later by Kuntscher ${ }^{2}$ most femoral diaphyseal fractures were treated non-operatively. Since the advent and popularization of intramedullary nailing the treatment of femoral shaft fractures has become a good, safe and reproducible procedure for the successful management of femoral shaft fractures. Many orthopedic surgeons have been trained well in the nailing of femoral shaft fractures and commonly treat these injuries. However, many femoral shaft fractures are complicated by associated fractures, extensive comminution, extensive contamination, arterial injury, and compartment syndrome. Other problematic situations include existing non-union with broken hardware, deformed nails with acute injury, and associated femoral shaft and femoral neck fractures. The management of these complex femur fractures is not common and demands special techniques to obtain a successful outcome. The objective of the study was to assess the various post-operative outcomes of the interlocking nail of fracture shaft of femur. The following were the outcomes assessed, time of union, range of motion of knee, infection, compartment syndrome, nerve palsy, iatrogenic fracture neck of femur, avascular necrosis of femoral head, malunion, delayed union, implant failure, shortening of limb, pain of hip and knee.

\section{METHODOLOGY}

In a prospective study a total of seventy-five patients of age group (18 to 57) years, of either sex, having fractures shaft of femur were treated by anterograde closed interlocking nail after taking written informed consent. Pre-operative evaluation was done which includes the history regarding the mode of injury. Clinical and radiological assessment fracture pattern were assessed with antero-posterior and lateral radiographic view of the thigh include hip and knee joint, and classified according to the radiological types. The study was conducted at patients admitted in B. P. Koirala Institute of Health Sciences, Dharan from March 2002 to Feb 2004.

The patients with previous deformity of the same limb mentally retarded and neurovascular injuries were excluded. We have considered delayed union to be present if clinical union of fracture did not take place within 24 weeks of the operation.

The patients were put on proximal tibial skeletal traction 1 to 2 weeks followed by anterograde closed interlocking nail. On the first postoperative day, gentle range of motion exercise of knee and hip was started; quadricepsstrengthening exercises within limits of pain tolerance and toe touch axillary crutch walking was started as early as possible (second day). Partial weight bearing axillary crutches was started when early callus formation was evident. Full weight bearing was allowed when callus formation bridged the fracture gap. The postoperative sutures were removed on the $12^{\text {th }}$ postoperative day. The second follow up visit was 6 weeks from the date of surgery. Further visits were at 6 weeks intervals.

\section{RESULTS}

The average age of patients was $35.5 \pm 10.2$ years with range 18 to 57 years. The male patients $(74.7 \%)$ were more frequent than females. The most common cause of fractures shaft of femur in this study was road traffic accident (69.3\%). Table 1 shows the frequency distribution on mode of injury encountered in this study.

\begin{tabular}{|l|c|c|}
\hline \multicolumn{2}{|l|}{ Table 1: Mode of injury $(\mathbf{n = 7 5 )}$} & \\
\hline Mode & Number of Patients & Percent \\
\hline Road Traffic Accidents & 52 & 69.3 \\
\hline Fall From Height & 20 & 26.7 \\
\hline Gunshot Injury & 3 & 4 \\
\hline Total & 75 & 100 \\
\hline
\end{tabular}

The most common types and radiological types of fractures were as shown in table 2 and 3 respectively.

\begin{tabular}{|l|c|c|}
\hline Table 2: Types of Fracture $(\boldsymbol{n}=\mathbf{7 5})$ & \\
\hline Type & Number of Patients & Percent \\
\hline Closed & 67 & 89.3 \\
\hline Open grade I & 3 & 4.0 \\
\hline Open grade II & 5 & 6.7 \\
\hline Total & 75 & 100 \\
\hline
\end{tabular}

\begin{tabular}{|lcc|}
\hline Table 3: Radiological Types $(n=75)$ & \\
\hline Radiological Types & Number of Patients & Percent \\
\hline Comminuted & 32 & 42.7 \\
\hline Oblique & 16 & 21.3 \\
\hline Segmental & 3 & 4.0 \\
\hline Spiral & 13 & 17.3 \\
\hline Transverse & 11 & 14.7 \\
\hline Total & 75 & 100 \\
\hline
\end{tabular}

The average union time in our study was $14.9 \pm 1.3$ weeks. The average union time with sex comparisons in our study male was $14.8 \pm 1.3$ weeks and female was $15.1 \pm 1.4$ weeks. P-value 0.48 There was $0-130^{\circ}$ range of motion in fifty-two cases (69.3\%), $0-120^{\circ}$ motion in eighteen cases $(24.0 \%)$ and $0-110^{\circ}$ motion in five cases $(6.7 \%)$. There was wound infection in four cases superficial infection in open gr. II but no deep infection. There was no compartment syndrome in our series. Two cases $(2.66 \%)$ had pudendal nerve palsy secondary to traction both of which recovered within four months. There was no iatrogenic fracture of neck femur and no cases of AVN femoral head in our series. There were six cases of malunion more than $10^{\circ}$ of external rotation in our series. There was no case of delayed union. All cases united within 24 weeks of date of operation. There were five cases of broken interlocking distal screw. There were four cases 
had shortening more than $1.5 \mathrm{~cm}$. Thirty percent of the patients suffered from hip pain while only $12 \%$ of the patients had knee pain and many patients became pain free after the removal of the nails.

\section{DISSCUSION}

Postoperative complications were mentioned in table 4.

Table 4: Results of series reporting treated by closed anterograde nailing of fractures shaft of femur.

\begin{tabular}{|c|c|c|c|c|c|c|c|c|c|c|}
\hline \multirow{2}{*}{ Authors } & \multirow{2}{*}{$\begin{array}{c}\text { No. of } \\
\text { Patients }\end{array}$} & \multirow{2}{*}{$\begin{array}{l}\text { Time } \\
\text { to } \\
\text { Union } \\
\text { Weeks }\end{array}$} & \multirow{2}{*}{ Infection } & \multirow{2}{*}{$\begin{array}{l}\text { Delay } \\
\text { Union }\end{array}$} & \multirow{2}{*}{$\begin{array}{c}\text { Range of } \\
\text { Motion } \\
\text { Knee < } \\
120^{\circ}\end{array}$} & \multicolumn{2}{|c|}{ Pain } & \multirow{2}{*}{$\begin{array}{l}\text { Pudendal } \\
\text { Nerve Palsy }\end{array}$} & \multirow{2}{*}{$\begin{array}{l}\text { Implant } \\
\text { Failure }\end{array}$} & \multirow{2}{*}{$\begin{array}{c}\text { Shortening } \\
>1.5 \mathrm{~cm}\end{array}$} \\
\hline & & & & & & Hip & Knee & & & \\
\hline Johnson KD et al $\left.\right|^{5}$ & 24 & 13.8 & & 4.2 & & & & & & \\
\hline Thoresen et $\mathrm{al}^{22}$ & 48 & 16 & & & & & & & & \\
\hline Christe et al ${ }^{23}$ & 117 & 17 & & $2(1.7 \%)$ & & & & & $2(1.7 \%)$ & \\
\hline JG Seiler ${ }^{24}$ & 89 & 13.1 & $1.10 \%$ & $1.10 \%$ & & & & $2(2.3 \%)$ & & \\
\hline M.Braten et $\mathrm{al}^{25}$ & 116 & & $0.90 \%$ & & & $26 \%$ & $20 \%$ & & & \\
\hline Present study & 75 & $14.9 \pm 1.3$ & & & $5(6.7 \%)$ & $32 \%$ & $12 \%$ & $2(2.6 \%)$ & $5(6.7 \%)$ & $4(5.3 \%)$ \\
\hline
\end{tabular}

After reviewing the articles, Table 4, various techniques and implants evolved to stabilize these fractures. Early management included ORIF using plates ${ }^{3,4,}$ open intramedullary nailing with cerclage wires ${ }^{5,6}$, and external fixation ${ }^{7,8,9}$. These techniques have been largely abandoned because of a considerable complication profile the success of closed intramedullary nailing in the treatment of femoral shaft fractures.

Closed intramedullary nailing has become the standard of care for both closed and open femoral shaft fractures. Chapman ${ }^{10}$ reported no infections and good functional results after delayed (10-14 days after injury) closed intramedullary nailing of open femur fractures, but this technique neglected the benefits of early patient's mobilization. Brumback ${ }^{11}$ et al reported no infection, Winquist et $\mathrm{al}^{12}$ reported $2 \%$ infection and Lhowe \& Hansen ${ }^{13}$ reported $5 \%$ infection rate.

Wiss et al $^{14}$ reported segmental femoral shaft fractures occur $5 \%$ of femoral shaft fractures. In our study segmental femoral shaft fractures occur $4 \%$. Segmental femoral shaft fractures result from high-energy injuries and usually accompanied by massive soft tissue damage.

Bennett et al ${ }^{15} 1993$ reported an ipsilateral fracture of the femoral neck is a significant finding in patients with a femoral shaft fracture, occurring in $2 \%$ to $6 \%$ of femoral shaft fractures ${ }^{12,15,16,17}$. In our study ipsilateral fracture of the femoral neck with a femoral shaft fracture occur $2.6 \%$. Frequently, the femoral neck fracture is not initially diagnosed; several series have shown that as many as 33\% of associated femoral neck fractures were not initially diagnosed $^{15,16,18 \text {. }}$

Femoral shaft fractures resulting from gunshot injuries based on the kinetic energy $\left(\mathrm{KE}=1 / 2 \mathrm{mv}^{2}\right)$ of the projectile. Low-energy injuries usually occur secondary to handgun shots in which the velocity of the projectile is less than 1000 $\mathrm{ft} / \mathrm{s}$ or from close-range shotguns in which the mass of the projectile factors significantly to increase the kinetic energy imparted to the tissues ${ }^{19,20}$. Femoral shaft fractures resulting from low-energy gunshot wounds can be thought of as type 1 open fracture. Treatment of the open wound does not require a formal irrigation and debridement, and good results have been reported with minimal, local wound care ${ }^{21}$. In our study femoral shaft fractures resulting from gunshot injuries occur $4 \%$ and manage as closed reamed nailing.

On the average, the time to union in our series was $14.9 \pm 1.3$ weeks which is comparable with Thoresen et a ${ }^{22} 16$ weeks, Johnson et al ${ }^{5} 13.8$ weeks, Christe et al $(1988)^{23} 17$ weeks. We have considered delayed union to be present if clinical union of fracture did not occur within 24 weeks of the operation. In our series there were no cases of delayed union.

There was no deep infection in our series, but there were 4 cases of superficial infection in open grade II fracture cases. All the cases had use antibiotics second-generation cephalosporin that is continued for intravenous 72 hours post-operatively and oral antibiotics for 12 days. This rate much more than that reported by Klemm and Borner (1986) ${ }^{24}$, Kempt et al (1985) ${ }^{25}$, Seiler and Swionthowski (1991) ${ }^{24}$ and Braten et al (1995) $)^{25}$. 
In our series there were 6 cases of unitted in malunion with $10^{\circ}$ of external rotation and 4 cases had shortening more than $1.5 \mathrm{~cm}$. Braten et $\mathrm{al}^{25}$ reported that $39.1 \%$ of the patients with an external rotation deformity of more than $15^{\circ}$ were actually symptomatic.

In our series $32 \%$ of the patients suffered from hip pain while only $12 \%$ of the patients had knee pain and many patients became pain free after the removal of the nails. Braten et al ${ }^{25}$ reported that $26 \%$ of patients had hip pain and $20 \%$ had knee pain. We had 5 cases $(6.7 \%)$ of broken interlocking screw, which is not a major complication.

In our series two cases (2.66\%) had pudendal nerve palsy secondary to traction which is recovered in 4 months. Seiler and swiontkowski $(1991)^{23}$ reported one peroneal and one pudendal nerve palsy, both of which recovered within 6 months.

\section{CONCLUSION}

An overall analysis of the results in table 4 shows that in comparison to previous studies results of our study were similar. We conclude that anterograde reamed femoral nailing provides excellent results in the management of fractures shaft of femur.

\section{LIMITATION OF THE STUDY}

None

\section{ACKNOWLEDGEMENT}

None

\section{CONFLICT OF INTEREST}

None

\section{REFERENCES}

1. Hey-Groves EW: Some clinical and experimental observation on the operative treatment of intramedullary pegs.BMJ 1912; 2:11021105.

2. Kuntscher G.Die Marknagelung von knochenbruchen. Langrch Arch Chir 1940;200; 443-455.

3. Magerl F, Wyss A, Brunner $\mathrm{CH}$, el al: plate osteosynthesis of femoral shaft fractures in adults : A follow-up study. Clin Orthop 138:62-73, 1979.

4. Ruedi TP, Luscher JN: Results after internal fixation of comminuted fractures of the femoral shaft with DC plates. Clin Orthop 138:74-76, 1979.

5. Johnson KD, Johnston DWC, Parker B: Comminuted femoral shaft fractures; Treatment by roller traction, cerlage wires and an intramedullary nail or an interlockimg intramedullary nail. JBJS Am 66:1222-1235, 1984

6. Tscherne $\mathrm{H}$, Hass $\mathrm{N}$, Krettek $\mathrm{C}$ : Intramedullary nailing combined with cerclage wires in the treatment of fractures of the femoral shaft. Clin Orthop212:62-67, 1986.

7. Alonso J, Geissler W Hughes JL: External fixation of femoral fractures; Indication and limitations. Clin orthop 241:83-88, 1989.

8. Habboushe MP: Al-Rasheed Military Hospital external fixation system for compound missile wounds of bone. Injury 15:388-389, 1984

9. Murphy CP, D' Ambrosia RD, Dabezies EJ, et al: Complex femur fractures; Treatment with the Wagner external fixation device ot the Grosse-Kempf interlocking nail. J Trauma 28:1553-1561, 1988.

10. Chapman MW: The role of intramedullary fixation in open fractures, Clin orthop 212:26-34, 1986.

11. Brumback RJ, Ellison PS, Poka A, et al: Intramedullary nailing of open fractures of the femoral shaft. JBJS Am 71:1324-1330, 1989

12. Winquist RA, Hansen JST, Clawson DK: Closed intramedullary nailing of femoral fractures: a report of five hundred and twenty cases. JBJS Am 66:529-539, 1984.
13. Lhowe DW, Hansen ST: Immediate nailing of open fractures of the femoral shaft. JBJS Am 70: 812-820, 1988

14. Wiss $D$, Brien W, Stetson w: interlocked nailing for treatment of segmental fractures of the femur. JBJS Am 72:724-728, 1990.

15. Bennett FS, Zinar DM, Kilgus DJ: Ipsilateral hip and femoral shaft fractures.Clin orthop 296; 168-177, 1993.

16. Swiontkowski MF, Hansen ST Jr, Kellam J: Ipsilateral fractures of the femoral neck and shaft: A treatment protocol. JBJS Am 66:260-268, 1984.

17. Wu CC, Shih $\mathrm{CH}$ : Ipsilateral femoral neck and shaft fractures: Retrospective study of 33 cases. Acta orthop Scand 62: 346-351, 1991

18. Swiontkowski MF: Ipsilateral femoral shaft and hip fractures.Orthop Clin North Am 18:73-84, 1987.

19. Demuth WE Jr: The mechanism of shotgun wounds. J trauma 11:219-229, 1971.

20. Shepard GH: High-energy, low velocity close range shotgun wounds. J Trauma 20:1065-1067, 1980.

21. Bergman $M$, Tornetta, $P$, KerinaM et al: Femur fractures caused by gunshot: treatment of immediate reamed intramedullary nailing. J trauma 34:783-785, 1993.

22. Thorensen $\mathrm{BO}$, Alho $\mathrm{A}$, Ekel $\mathrm{A}$ et al: interlocking intramedullary nailing in femoral shaft fractures, A report of 48 cases,JBJS ,67A;1313,1985.

23. Christie J, Court-Brown C, Kinninmonth AW, Howie CR, Intramedullary locking nails in the management of femoral shaft fractures. JBJS (Br),70-B,206-210,1988

24. Seiler JG, Swiontkowski MS, Prospective evaluation of the AO/ASIF universal femoral nail in the treatment of traumatic and reconstructive problems of the femur.J Trauma 31:121-126,1991

25. Barten M, Terjesen T,Rossvoll I,Femoral shaft fractures treated by intramedullary nailing.A follow up study focusing on problems relating to the method.Injury,26:379-383,1995 